\title{
How much does care in palliative care wards cost in Poland?
}

\author{
Aleksandra D. Ciałkowska-Rysz ${ }^{1}$, Wieslawa Pokropska², Jacek Łuczak ${ }^{3}$, Anna Kaptacz², \\ Andrzej Stachowiak ${ }^{5}$, Krystyna Hurich ${ }^{5}$, Monika Koszela ${ }^{5}$
}

\author{
${ }^{1}$ Palliative Care Ward, Department of Oncology, Medical University of Lodz, Lodz, Poland \\ ${ }^{2}$ Elbląg Hospice of Dr. Aleksandra Gabrysiak, Elblag, Poland \\ ${ }^{3}$ Hospice Palium, University Hospital of the Lord's Transfiguration, Poznan University \\ of Medical Sciences, Poznan, Poland \\ ${ }^{4}$ Hospice, Czestochowa, Poland \\ ${ }^{5}$ Sue Ryder House, Pallmed, Bydgoszcz, Poland
}

Submitted: 22 September 2015

Accepted: 13 October 2015

Arch Med Sci 2016; 12, 2: 457-468

DOI: 10.5114 /aoms.2016.59272

Copyright $\odot 2016$ Termedia \& Banach

\section{Abstract}

Introduction: The main task of palliative care units is to provide a dignified life for people with advanced progressive chronic disease through appropriate symptom management, communication between medical specialists and the patient and his family, as well as the coordination of care. Many palliative care units struggle with low incomes from the National Health Fund (NHF), which causes serious economic problems. The aim of the study was to estimate of direct and administrative costs of care and the actual cost per patient per day in selected palliative care units and comparison of the results to the valuation of the NHF.

Material and methods: The study of the costs of hospitalization of $175 \mathrm{pa}$ tients was conducted prospectively in five palliative care units (PCUs). The costs directly associated with care were recorded on the specially prepared forms in each unit and also personnel and administrative costs provided by the accounting departments.

Results: The total costs of analyzed units amounted to 209002 EUR (898 712 PLN), while the payment for palliative care services from the NHF amounted to 126010 EUR (541 844 PLN), which accounted for only $60 \%$ of the costs incurred by the units. The average cost per person per day of hospitalization, calculated according to the actual duration of hospitalization in the unit, was 83 EUR ( 357 PLN), and the average payment from the NHF was 52.8 EUR (227 PLN). Underpayment per person per day was approximately 29.2 EUR (125 PLN).

Conclusions: The study showed a significant difference between the actual cost of palliative care units and the level of refund from the NHF. Based on the analysis of costs, the application has been submitted to the NHF to change the reimbursement amount of palliative care services in 2013.

Key words: palliative care, cost analysis, cost of care, financing, palliative care unit.

\section{Introduction}

Palliative care in Poland and many other countries in the world is developing very dynamically in order to provide patients who suffer from terminal illnesses with the highest quality care at the end of life. In this

\author{
Corresponding author: \\ Aleksandra D. Ciałkowska- \\ Rysz MD, PhD \\ Palliative Care Ward \\ Department of Oncology \\ Medical University of Lodz \\ 113 Żeromskiego St \\ 90-549 Lodz, Poland \\ Phone: +48 601965190 \\ Fax: +48 426319509 \\ E-mail: olarysz@rmed.pl
}


period of life of patients with severe disease, the appropriate symptomatic treatment, communication between medical staff and the patient and his family, as well as the coordination of care are most important. Although the compassion and the commitment to ensure the autonomy and dignity of seriously ill persons should be a sufficient justification for adequate funding of palliative care, the growing social demand for palliative care and restricted amount of money make cost counting and palliative care effectiveness crucial in decision-making by managers and payers of medical services [1, 2]. This is particularly important in regard to the most expensive form of care - hospitalization in palliative medicine wards [3]. Residential care, carried out both in hospitals and in specialized hospice units, is one of the basic forms of palliative care [4]. The units of account most commonly used in palliative medicine wards are costs of hospitalization per person per day or total cost of hospitalization, which are, according to the results of many comparative studies, significantly lower than the costs of care in the case of a similar group of patients in ordinary hospital wards [5-9]. The costs of care offered to palliative care patients depend among other things on the diagnosis, functional status, overall status and age of the treated patients, but also on the type of services, duration of hospitalization and medical procedures used and the degree of cooperation with other forms of palliative care, especially domestic ones $[1,10-13]$. The results of one multicenter study conducted in hospitals in Belgium demonstrated higher costs of care in palliative care wards than in ordinary wards, which also provided care to terminally ill patients [1]. In Poland, the debate concerning the financing of palliative care including the underestimated costs of care per person per day in palliative medicine wards is carried out mainly by health care providers, palliative medicine specialists and the national consultant in the form of appeals for the need to increase the amount of money for palliative care and a proper unit valuation of provisions. These appeals are addressed to decision-makers of the Ministry of Health and the main payer the National Health Fund (NHF). So far, only the results of one pharmacoeconomic study which retrospectively analyzed the costs of hospitalization of 58 patients with non-small cell lung cancer have appeared in Poland [14]. Neither the Ministry of Health nor the NHF has carried out an analysis of the cost of provisions of palliative care services as well as their proper valuation. For healthcare providers in the country, who have performed for many years a systematic analysis of the cost of palliative medicine wards, the present reimbursement amount for residential services seems to be detached from the real needs of patients and economic determinants of health services. The proof is that there has not been any significant change in the valuation of provisions for palliative care services since 2007. Therefore, the estimation of costs of palliative care per person per day was one of the demands of the Palliative and Hospice Care Team established in 2012 at the Ministry of Health under the leadership of the national consultant in palliative medicine. The national consultant appointed a working team to perform calculations of actual costs incurred by service providers [15].

\section{Material and methods}

\section{Units of palliative care wards}

Five wards in 5 cities (Lodz, Elblag, Poznan, Czestochowa and Bydgoszcz) out of 148 palliative care units (PCUs) operating in Poland in 2012 [16] were chosen in a pragmatic manner, and they agreed to participate in this study. These wards represented a high standard of organization of palliative care services, had a qualified medical team and manager, and provided services under a contract with the NHF [4]. Palliative medicine wards in the selected units had from 8 to 28 beds. Two wards were in the structure of university hospitals and the rest represented freestanding, independent hospices managed by associations and a commercial law company. Most of them, apart from palliative medicine wards, also ran hospices, palliative medicine clinics and postgraduate education for doctors and nurses, and university units also provided students' education. Three units had the accreditation of the Ministry of Health to conduct the specialization in palliative medicine and certified quality management systems ISO 9001:2008.

\section{Patients and conditions of hospitalization in palliative care units}

Special forms were prepared for patients hospitalized in PCUs in June 2012 in order to calculate direct costs of hospitalization using micro cost methods. Economic analysis of forms of patients who met the criteria of ICD-10 required for the settlement of hospitalization with the NHF was performed. Among them there were patients with: cancers (COO to D48), consequences of inflammatory diseases of the central nervous system (G09), diseases caused by HIV (B20-24), systemic primary atrophy within the central nervous system (G10-13), cardiomyopathies (142-43), respiratory failure (J96) and decubitus bedsores (L89) [4, 17]. In accordance with the Regulation of the Ministry of Health, also the care of the patient involving his hospitalization for a period of no longer than 10 days was possible [4]. Procedures related to the 
analysis of hospitalization costs did not influence the way of admittance, treatment and hospitalization time. Wards participating in the study in accordance with the terms of ongoing contracts with the NHF provided health services administered by nurses, doctors, physiotherapists and psychologists in a $24 \mathrm{~h}$ a day, 7 days a week scheme. Due to the stationary round-the-clock nature of the care provided in the PCU, it was necessary to employ an epidemiological nurse and a pharmacist.

Units running a PCU which participated in this study provided 1 to 3 person rooms, isolation rooms, treatment rooms, daily residence halls, rooms tailored to the needs of disabled people and rooms for the temporary storage of corpses [18]. Moreover, units located in university hospitals used the hospital's pharmacy, and the rest of the wards used a pharmaceutical department [19]. In accordance with other regulations, units running a PCU should secure adequate storage of medical records in the archives [20]. As required by the NHF, palliative care wards were equipped with adequate rehabilitation equipment adapted for the needs of disabled people, with portable syringe pumps, oxygen concentrators or other sources of oxygen, nebulizers, etc. The PCUs were also obliged to provide necessary medicines, dressings, disinfectants and hygiene products, transport and diagnostic tests to patients [4].

Due to the need of medical staff training, as well as an obligation to train professionals, many units had educational halls, libraries and other necessary training aids, as well as specialized committees required for accredited bodies [21].

Analyzed PCUs had management and administrative departments, including accounting departments, personnel and payment departments as well as economic cells associated with the delivery of medicines and medical materials, water, heat and energy, and employed staff responsible for current maintenance of building safety. These units also bore the expenses associated with the insurance of medical activities and buildings as required by regulations [22].

\section{Economic analysis of hospitalization costs}

Hospitalization costs in PCUs included costs paid by the health care provider directly for patient care and general costs required to maintain the proper structure and organization of medical activities of PCUs. Direct costs of hospitalization were associated with diagnostics-treatment and welfare processes. They could be ascribed to the patient. These costs included primarily expenditures on medicines, bandages, diagnostic tests, the cost of performed medical procedures (rehabilitation, specialist consultations, and transport of patients) as well as the costs of medical per- sonnel work, without the cost of training [23]. The latter costs were included in the overhead costs. The personnel costs included salaries for staff employed in PCUs on employment contracts, orders or contract workers, as well as costs associated with legal fees and taxes on salaries. Overhead costs included the expenditures made on the implementation of treatment and the care of patients, which could not be directly ascribed to the patient but which were necessary to ensure the proper care process in the analyzed unit. These included the following costs: administrative, managerial, amortization, fuel and car parts necessary to transport patients, cleaning and disinfecting products, office supplies, water, heat and energy supplies, ongoing maintenance, outsourcing: sterilization, disposal, nutrition services, laundry, IT, telecommunication and postal services, rental costs, staff training, taxes and fees and other costs of unit business. Expenditures on the heating of PCUs were calculated for the analyzed month as the average monthly cost of the total cost of heating for the whole year. Overhead costs were calculated using the 'top-down' method for general costs for the month, and then they were divided by the selected units of hospitalization, i.e. the number of patients or the number of patients per day, in order to properly assess the costs of patient hospitalization and costs of hospital stay per patient per day.

Moreover, on the basis of cost data from PCUs, direct costs, overall costs and total costs for the population of patients hospitalized in the same period, in the analyzed units were calculated. The average cost per person per day of hospitalization of a study population was calculated on the basis of medical statistics of PCUs and statistics required for the settlement of a contract agreement with the National Health Fund. Then, the average cost per day per person and the payment for care per person per day used in the Provincial Units of the NHF (PU NHF) were compared. The average direct cost, and general and patient's total hospitalization costs were also calculated, and the revenue associated with the execution of contracts with PU NHF was compared with total costs incurred by analyzed units.

Mean hospitalization time was calculated by dividing the total number of days of hospitalization by the number of patients in the analyzed population. Differences in hospitalization time between CPUs and the National Health Fund statistics stemmed from the fact that the payer treated the admission day and discharge (death) day as one [24].

Personnel and payment as well as accounting records concerning staff employment were used to calculate work time per employee expressed 
in hours, and the average cost of staff's working hours.

\section{Identification and measurement of used resources}

From 1 to 30 June 2012, data on direct costs for all patients were collected every day with the help of the method of micro costs. During day and night duties, trained nurses made the records (using special forms) concerning the use of disposable equipment, medicines, dressing materials, specialized dressings and other materials used in treatment and care for each patient. Also the data on the number and type of performed laboratory tests, imaging examinations, specialist consultations and treatments were collected. These forms have been created on the basis of the cost card annexed to the proposal to change conditions for making and implementing contracts arising from the procedure announced by the NHF in its communication from 8 September 2011 (procedure No. 2011/001/DSOZ/PZZ/1.0). Then, a monetary value was assigned to medical materials used in the treatment process on the basis of invoices and transactions resulting from agreements with suppliers. Data concerning duration of hospitalization, main diagnosis, gender, age and mode of discharge of a patient from the PCU were collected on additional form. Costs incurred by the patient's family or caregivers, as well as the volunteer work provision, were not included in direct costs. Upon completion of invoices and payments for the analyzed month, accounting departments in units sent forms with direct and general costs electronically to the unit coordinating overall calculations for all PCUs participating in the analysis of hospitalization costs.

In the analyzed units in June, no over-normative costs were observed or lowered, no repairs or modernizations were performed, no expensive equipment was purchased and no new staff was employed. Data concerning payment for health services associated with ongoing contracts with the NHF were obtained from accounting departments of units participating in the study. On this basis, the economic result for the analyzed month was calculated.

\section{The organization and analysis scheme in selected palliative care units}

The analysis of cost of hospitalization was conducted prospectively in five PCUs in June 2012. The coordinating unit prepared appropriate cost forms with instructions how to complete them in electronic form, and they were transmitted to the coordinators of analysis in each PCU for the daily collection of data on the used resources and per- formed medical procedures. These forms after verification by study coordinators were forwarded to the accounting departments in order to complete data from invoices from suppliers. Afterwards, the completed cost forms were forwarded to the coordinating unit, where they were checked for correctness, and an electronic database in Microsoft Office Excel was created for individual patients from analyzed PCUs. Data on direct costs, salaries and general administrative expenses were collected until 30 September 2012. An electronic database containing direct costs and general administrative expenses was used to carry out further cost analyses and for statistical analysis.

\section{Statistical analysis}

The results of analysis of total costs, direct, overhead costs of hospitalizations and their percentage share in total costs, mean cost of hospitalization per person on the basis of hospitalization duration and NHF settlements, mean direct cost, overhead costs and costs of hospitalization per person per day in the studied PCUs are shown as the arithmetic mean, median, minimum-maximum range, deviation and standard error. All calculations were performed using the statistical program IBM SPSS 21.

\section{Results}

General characteristics of the structure and activities of palliative care units participating in the study of costs in palliative care wards in June 2012 are summarized in Table I. In June 2012, 175 patients (102 women, 73 men aged $67 \pm 15$ ) were hospitalized in five analyzed PCUs. The total duration of hospitalization in the PCUs was 2550 days, and duration of hospitalization calculated in accordance with the requirements of the $\mathrm{Na}$ tional Health Fund was shorter by 167 (6.5\%) days and amounted to 2383 days (Table II). Patients with cancers constituted the largest group (156; $89 \%)$ (14\% had lung cancers, $9 \%$ cancers of large intestine, $7 \%$ of breast, $6 \%$ of ovary, $5 \%$ of pancreas and $49 \%$ other cancers). Moreover, $11 \%$ of patients suffered from non-cancer diseases according to ICD-10, such as: bedsores (5\%), cardiomyopathy (1\%) and other (5\%). Among the most common reasons for admittance of patients to the PCUs were difficult to control symptoms such as pain, shortness of breath, vomiting, and hard-toheal wounds and bedsores, but also the need to perform diagnostic tests. Harsh living conditions, failure of caregivers and families to provide care and the need for 24-hour care of isolated people and dependents were other very frequent indications for hospitalization. The mean duration of treatment for the entire study population was 


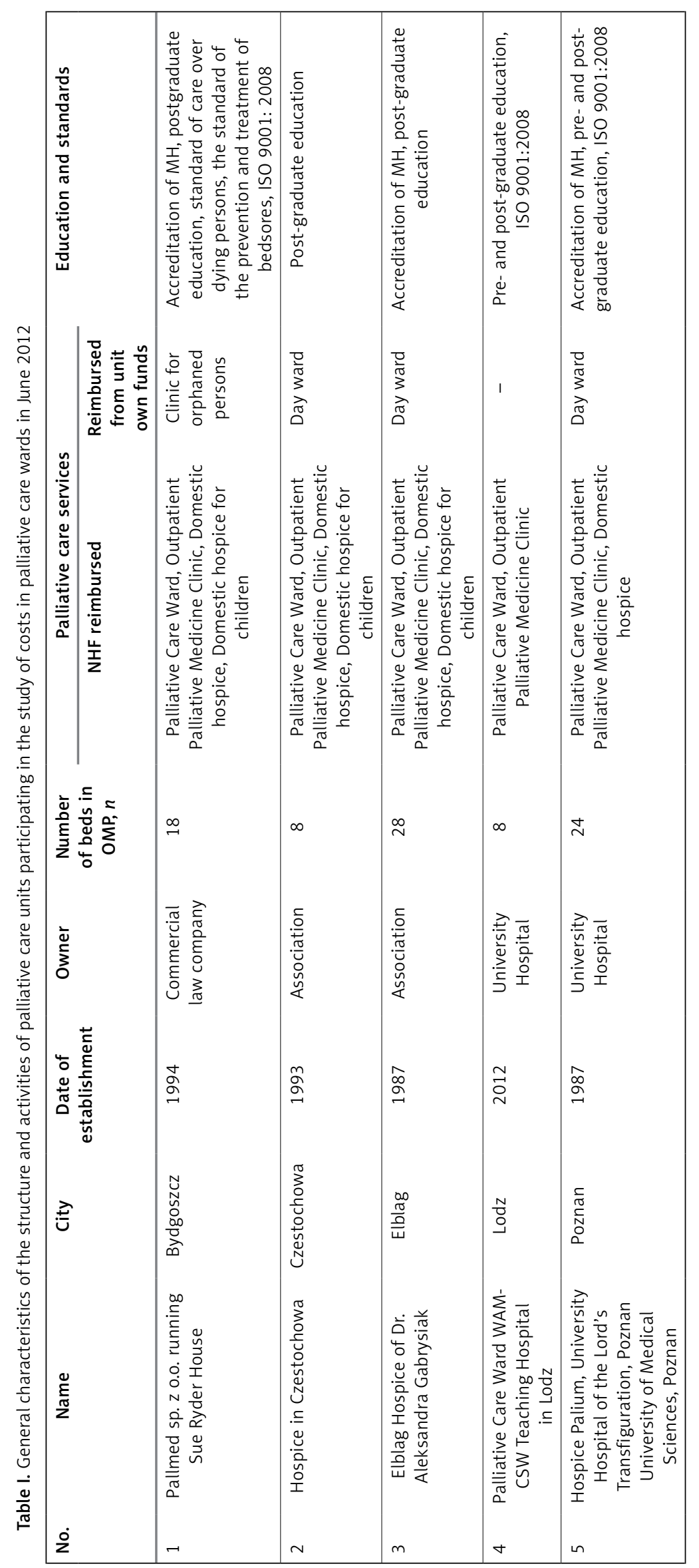


Table II. Medical statistics in the studied PCUs in June 2012

\begin{tabular}{|c|c|c|c|c|c|c|c|}
\hline \multicolumn{3}{|c|}{ Palliative care wards } & \multirow{3}{*}{$\begin{array}{c}\text { Mean } \pm \text { SE } \\
31 \pm 7\end{array}$} & \multirow{2}{*}{$\begin{array}{c}\text { Median } \\
34\end{array}$} & \multirow{2}{*}{$\begin{array}{l}\text { Admit- } \\
\text { tance }\end{array}$} & \multicolumn{2}{|c|}{ Discharge } \\
\hline & & & & & & & \\
\hline \multirow{3}{*}{$\begin{array}{l}\text { Number of } \\
\text { patients } \\
(n=175)\end{array}$} & With cancers & $156(89)$ & & & & $\begin{array}{c}\begin{array}{c}\text { To home } \\
\text { or other } \\
\text { unit }\end{array} \\
29 \\
\end{array}$ & $\begin{array}{c}\text { Deaths } \\
61\end{array}$ \\
\hline & $\begin{array}{l}\text { With non-cancer } \\
\text { diseases }\end{array}$ & $19(11)$ & $4 \pm 1$ & 4 & & 10 & - \\
\hline & Total number of patients & $175(100)$ & $35 \pm 7$ & 41 & $93(57)$ & $39(22)$ & $61(35)$ \\
\hline \multirow{2}{*}{$\begin{array}{l}\text { Total time of } \\
\text { hospitalization } \\
\text { [days] }\end{array}$} & $\begin{array}{l}\text { According to } \\
\text { hospitalization in } \mathrm{PCU}^{*}\end{array}$ & 2550 & $510 \pm 126$ & 551 & & & \\
\hline & $\begin{array}{l}\text { In accordance with NHF } \\
\text { settlement }^{\star \star}\end{array}$ & 2383 & $477 \pm 119$ & 512 & & & \\
\hline \multicolumn{2}{|c|}{$\begin{array}{l}\text { Mean duration of hospitalization*, } \\
\text { mean } \pm \text { SE [days] }\end{array}$} & - & $15 \pm 1$ & $14 \pm 1$ & & & \\
\hline \multicolumn{2}{|c|}{ Percentage of bed occupancy [\%] } & - & $97 \pm 3$ & 97 & & & \\
\hline
\end{tabular}

Table III. Total costs, direct and overhead costs in the analyzed PCUs in June 2012

\begin{tabular}{|lcc|}
\hline Cost category & $\begin{array}{c}\text { SUM [PLN; (\%)] } \\
N=175\end{array}$ & $\begin{array}{c}\text { SUM [EUR; (\%)] } \\
N=175\end{array}$ \\
\hline Direct & $624610(70)$ & $145182(70)$ \\
\hline Overhead costs & $274102(30)$ & $63711(30)$ \\
\hline Total & $898712(100)$ & $208893(100)$ \\
\hline
\end{tabular}

$1 E U R=4.30$ PLN

15 days. Percentage of the use of beds by patients in the studied wards was very high (97\%). The analysis of patients' movement revealed that in the analyzed time, 93 new patients were admitted and 100 persons were discharged, while 61 (61\%) patients died in palliative care units.

Women represented the largest group in the study population (58\%). Cancer occurred in $89 \%$ of patients and lung cancer, colorectal cancer and breast cancer were the most common. In patients with non-cancer diseases bedsores were most frequent (5\%).

\section{Economic results}

The total cost of hospitalization in the analyzed month was 209002 EUR (898 712 PLN), the total direct costs was 145258 EUR (624 610 PLN) (70\%), and the overhead costs was 63 744.6 EUR (274 102 PLN) (30\%) (Table III).

The total costs of salaries for medical and non-medical employees including derivatives (Social Insurance Institution, taxes) in the studied PCUs accounted for the largest percentage of direct costs (75\%) and overall (52\%) and amounted to 108475.3 EUR (466 444 PLN) (Table IV). Costs associated with diagnostic and therapeutic procedures accounted for $18 \%$ and $25 \%$ of total costs and direct costs and amounted to 36782.8 EUR
(158 166 PLN) (Table IV). In turn, in direct costs associated with medical procedures, costs of medicines and dressing materials had the largest share and amounted to 14 157.2 EUR (60 876 PLN) (10\%) and 13594.4 EUR (58 456 PLN) (9\%) respectively, while costs of laboratory tests and imaging examinations had the lowest share 1797 EUR (7727 PLN) (1\%) (Table IV). Overhead costs in the analyzed wards amounted to 63744.7 EUR (274 102 PLN), which represented $30 \%$ of total costs (Table IV).

The total number of medical and non-medical staff (medical secretaries, chaplain, caregivers, and paramedics) employed in the units amounted to 300 people; the largest group comprised workers employed on an employment contract - 179 (60\%) persons, on commission contracts - 34 (11\%) people and on civil law contracts - 87 (29\%) people. These employees worked in the studied month for a total of $35569 \mathrm{~h}$ (Table V). The average gross cost of $1 \mathrm{~h}$ of work of staff in PCUs was 3 EUR (13 PLN) (Table V).

\section{Cost of hospitalization per person per day}

During the calculation of cost of hospitalization per person per day the differences in the method of counting of the duration of hospital stay by PCUs and the NHF were taken into account (Table VI). The mean cost of hospitalization per person per day in the studied PCUs calculated on the basis of medical statistics of PCUs was 81.9 EUR (352 PLN), while calculated on the basis of NHF rules it was higher by $7 \%$ and was 87.7 EUR (377 PLN).

The percentage share of direct costs in total costs was higher and was 57 EUR (245 PLN), which accounted for $70 \%$ of the mean cost of hospitalization per person per day. In turn, employees' 
Table IV. Categories and direct costs and overhead costs of hospitalizations and their percentage share in total costs in the studied PCU in June 2012

\begin{tabular}{|lcccc|}
\hline No. & Cost categories & Sum [PLN (\%)] & $\begin{array}{c}\text { Sum } \text { [EUR (\%)] }_{N=175} \\
\boldsymbol{N}=175\end{array}$ & $\begin{array}{c}\text { Share in total } \\
\text { costs (\%) }\end{array}$ \\
\hline 1.0 & Directs costs associated with: & 624610 & 145258.1 & 70 \\
\hline 1.1 & Medical procedures & $158166(25)$ & 36782.8 & 18 \\
\hline 1.1 .1 & Drugs & $60876(10)$ & $14157.2(25)$ & 7 \\
\hline 1.1 .2 & Medical materials & $58456(9)$ & $13594.4(10)$ & 6 \\
\hline 1.1 .3 & Consultations, advice and treatment & $31107(5)$ & $7234.2(9)$ & 4 \\
\hline 1.1 .4 & Diagnostic tests & $7727(1)$ & $1797(5)$ & 1 \\
\hline 1.2 & Personnel's salaries with derivatives & $466444(75)$ & $108475.3(1)$ & 52 \\
\hline 1.2 .1 & (dues and taxes) & $370906(80)$ & $86257.2(75)$ & 41 \\
\hline 1.2 .2 & Salaries & $95538(20)$ & $22218.1(80)$ & 11 \\
\hline 2.0 & Derivatives & 274102 & $63744.7(20)$ & 30 \\
\hline & Unit's total costs & 898712 & 209002.8 & 100 \\
\hline
\end{tabular}

$1 E U R=4.30 P L N$.

Table V. Employment of medical and non-medical staff and their salaries in the studied PCU in June 2012

\begin{tabular}{|c|c|c|}
\hline \multirow{2}{*}{$\begin{array}{l}\text { Contract of } \\
\text { employment }\end{array}$} & Number of posts, $n(\%)$ & $179(60)$ \\
\hline & Working time $[\mathrm{h}]$ & $23863 ; 1$ worker/post $=133.3 \mathrm{~h}$ \\
\hline \multirow[t]{2}{*}{ Commission contract } & Number of employed persons, $n(\%)$ & $34(11) ; 1$ worker $=246 \mathrm{~h}$ \\
\hline & Number of worked hours, $n$ & 8375 \\
\hline \multirow[t]{2}{*}{ Civil law contracts } & Number of employed persons, $n(\%)$ & $87(29)$ \\
\hline & Number of worked hours, $n$ & $3331 ; 1$ contract worker $=38.3 \mathrm{~h}$ \\
\hline \multicolumn{2}{|c|}{ Total number of employees, $n$} & 300 \\
\hline \multicolumn{2}{|c|}{$\begin{array}{l}\text { Total working time }[\mathrm{h}] \\
\text { Number of posts on the basis of full working time }(152 \mathrm{~h} / \text { post })\end{array}$} & $\begin{array}{c}35569 \\
234\end{array}$ \\
\hline \multicolumn{2}{|c|}{$\begin{array}{l}\text { Salaries [PLN (EUR)] } \\
\text { Cost of } 1 \mathrm{~h} \text { of personnel's work net/gross [PLN (EUR)] }\end{array}$} & $\begin{array}{c}370906(86212) \\
10 / 13(2 / 3)\end{array}$ \\
\hline \multicolumn{2}{|c|}{ Social insurance in Social Insurance Company (ZUS) [PLN (EUR)] } & 91162 (21 189) \\
\hline \multicolumn{2}{|c|}{ Other costs of fringe benefits [PLN (EUR)] } & $4375\left(\begin{array}{lll}1 & 017\end{array}\right)$ \\
\hline \multicolumn{2}{|c|}{ Total personal costs [PLN (EUR)] } & 466444 (108 418) \\
\hline
\end{tabular}

$1 E U R=4.30 \mathrm{PLN}$.

salaries amounted to 42.8 EUR (184 PLN), which accounted for $52 \%$ of the mean cost of hospitalization per person per day (Table VI).

The mean direct cost, overhead costs and cost of hospitalization per person per day in the studied PCU were 57, 25.1, 81.9 EUR $(245,108$ and $352 \mathrm{PLN})$, respectively. The percentage share of the mean direct costs in the mean total cost of care per person per day for the entire population of hospitalized patients was 70\% (Table VI). A comparative analysis of the mean cost of hospitalization per person per day and mean payment for care per person per day used by the payer demonstrated a significant difference, which was 29.1 EUR (125 PLN) (Table VI).

Mean cost of direct, overhead costs and total cost of patient's hospitalization in the units were 830, 364.2 and 1194.2 EUR (3569, 1566 and 5135 $\mathrm{PLN})$, respectively (Table $\mathrm{VI})$.

Economic analysis of expenditures as well as revenues associated with NHF payment for health services in analyzed PCU revealed a significant economic loss in June, which amounted to 82992.6 EUR (356 868 PLN). Revenues covered only $60 \%$ of real monthly cost of care (Table VI). 
Table VI. Mean cost of hospitalization per person on the basis of hospitalization duration and NHF settlements, mean direct cost, overhead costs and costs of hospitalization per person per day, mean direct cost, overhead costs and total costs of patient's hospitalization, total costs and UP NHF payment for palliative care services in the studied PCUs in June $2012(N=171)$

\begin{tabular}{|c|c|c|c|c|c|c|c|}
\hline No. & & st categories & \multicolumn{2}{|c|}{$\begin{array}{l}\text { On the basis } \\
\text { of the duration } \\
\text { of PCU } \\
\text { hospitalization* } \\
{[\mathrm{PLN} \pm \text { SE (\%)] }}\end{array}$} & $\begin{array}{l}\text { On the basis } \\
\text { of the duration } \\
\text { of hospitalization } \\
\text { settled by NHF** } \\
{[P L N \pm S E(\%)]}\end{array}$ & $\begin{array}{c}\text { On the basis } \\
\text { of the duration } \\
\text { of PCU } \\
\text { hospitalization* } \\
\text { [EUR } \pm \text { SE (\%)] }\end{array}$ & $\begin{array}{l}\text { On the basis } \\
\text { of the duration } \\
\text { of hospitalization } \\
\text { settled by NHF** } \\
\text { [EUR } \pm \text { SE (\%)] }\end{array}$ \\
\hline 1.0 & & $\begin{array}{l}\text { Directs costs } \\
\text { sociated with: }\end{array}$ & \multicolumn{2}{|c|}{$245 \pm 22(70)$} & $262 \pm 14(70)$ & $57(70)$ & $61(70)$ \\
\hline 1.1. & $\mathrm{Me}$ & dical procedures & \multicolumn{2}{|c|}{$61 \pm 13(18)$} & $64 \pm 14(18)$ & $14(18)$ & $15(18)$ \\
\hline 1.1 .1 & & Drugs & \multicolumn{2}{|c|}{$24 \pm 5(7)$} & $26 \pm 5(7)$ & $6(7)$ & $6(7)$ \\
\hline 1.1 .2 & & dical materials & \multicolumn{2}{|c|}{$18 \pm 6(5)$} & $19 \pm 7(5)$ & $4(5)$ & $4(5)$ \\
\hline 1.1 .3 & Con & $\begin{array}{l}\text { ultations, advice } \\
\text { nd treatment }\end{array}$ & \multicolumn{2}{|c|}{$16 \pm 9(5)$} & $17 \pm 10(5)$ & $4(5)$ & $4(5)$ \\
\hline 1.1 .4 & & agnostic tests & \multicolumn{2}{|c|}{$4 \pm 2(1)$} & $5 \pm 2(1)$ & $1(1)$ & $1(1)$ \\
\hline 1.2 & & $\begin{array}{l}\text { onnel's salaries } \\
\text { ith derivatives } \\
\text { ues and taxes) }\end{array}$ & \multicolumn{2}{|c|}{$184 \pm 20(52)$} & $196 \pm 22(52)$ & $43(52)$ & $46(52)$ \\
\hline 1.2 .1 & & Salaries & \multicolumn{2}{|c|}{$146 \pm 16(41)$} & $156 \pm 17(41)$ & $34(41)$ & $36(41)$ \\
\hline 1.2 .2 & & Derivatives & \multicolumn{2}{|c|}{$38 \pm 4(11)$} & $40 \pm 4(11)$ & $9(11)$ & $9(11)$ \\
\hline 2.0 & & verhead costs & \multicolumn{2}{|c|}{$108 \pm 15(30)$} & $115 \pm 16(30)$ & $25(30)$ & $27(30)$ \\
\hline $\begin{array}{l}\text { Mean } \\
\text { per da }\end{array}$ & tal co & st per person & \multicolumn{2}{|c|}{$352 \pm 36(100)$} & $377 \pm 36(100)$ & $82(100)$ & $88(100)$ \\
\hline \multicolumn{3}{|c|}{$\begin{array}{l}\text { Difference between calculated } \\
\text { costs per person per day }\end{array}$} & \multicolumn{3}{|c|}{$25(7 \%)$} & \multicolumn{2}{|c|}{$6(7 \%)$} \\
\hline \multicolumn{2}{|c|}{$\begin{array}{l}\text { Mean cost } \\
\text { of hospital- } \\
\text { ization per } \\
\text { person per } \\
\quad \text { day }\end{array}$} & \multicolumn{2}{|c|}{$\begin{array}{l}\text { On the basis of medical } \\
\text { statistics of PCU } \\
{[P L N \pm \text { SE (\%)] }}\end{array}$} & \multicolumn{2}{|c|}{$\begin{array}{c}\text { On the basis of } \\
\text { medical statistics } \\
\text { of NHF } \\
{[P L N \pm \text { SE (\%)] }}\end{array}$} & $\begin{array}{l}\text { the basis of } \\
\text { ical statistics } \\
\text { of PCU } \\
R \pm \text { SE (\%)] }\end{array}$ & $\begin{array}{c}\text { On the basis of medical } \\
\text { statistics of NHF } \\
\text { [EUR } \pm \text { SE (\%)] }\end{array}$ \\
\hline Direct & osts & \multicolumn{2}{|c|}{$245 \pm 22(70)$} & 262 & $\pm 14(70)$ & $57(70)$ & $61(70)$ \\
\hline $\begin{array}{l}\text { Overhe } \\
\text { costs }\end{array}$ & & $108 \pm 15$ & & 115 & $\pm 16(30)$ & $25(30)$ & $27(30)$ \\
\hline Total c & & $352 \pm 36$ & & 377 & $\pm 36(100)$ & $82(100)$ & $88(100)$ \\
\hline $\begin{array}{l}\text { Mean } \\
\text { payme } \\
\text { for car } \\
\text { persor } \\
\text { day by } \\
\text { NHF }\end{array}$ & & & $227 \pm$ & & & 6 & \\
\hline $\begin{array}{l}\text { Mean } \\
\text { per da }\end{array}$ & ost of & hospitalization $\mathrm{p}$ & erson & & [PLN $\pm \mathrm{SE}(\%)]$ & & EUR (\%)] \\
\hline Direct & osts & & & & $3569 \pm 207(70)$ & & $830(70)$ \\
\hline Overh & $\mathrm{d} \cos$ & & & & $1566 \pm 93(30)$ & & $364(30)$ \\
\hline Total c & & & & & $5135 \pm 295(100)$ & & $194(100)$ \\
\hline & & & & & & [PLN (\%)] & [EUR (\%)] \\
\hline Total i & currec & costs according & PCU (a) & & & 8712 (100) & $208893(100)$ \\
\hline $\begin{array}{l}\text { Total } r \\
\text { by NH }\end{array}$ & $\begin{array}{l}\text { venue } \\
\text { (b) }\end{array}$ & s associated witl & e provi & of se & vices paid & $41844(60)$ & $125944(60)$ \\
\hline Differe & ice (a & - b) & & & & $56868(40)$ & $82949(40)$ \\
\hline
\end{tabular}




\section{Discussion}

Current difficulties in the financing of medical services in the healthcare system in this country affect to a large extent also the payment of the care of the seriously ill and dying. Despite the fact that in the last decade NHF increased financial resources for domestic and stationary palliative care, it is still insufficient to cover the needs of patients. Moreover, in 2007 there was a withold payment for stationary and domestic care per person per day and low valuation of health services during a visit in a palliative medicine outpatient clinic, which resulted in limitation of the availability of palliative care to patients and serious economic difficulties of health services providers. The main reasons for these difficulties included a lack of a reliable estimation of hospitalization costs in palliative care wards and lack of designation of the appropriate budget in the National Health Fund for the purposes of treatment during the last years of life. In Poland, palliative care concerns the vast majority of patients with advanced stages of cancer. The NHF assigns approximately 83720930.2 EUR (360 million PLN) to the treatment of cancers, which represents approximately $0.5 \%$ of the total budget of the NHF.

The results of recent pharmacoeconomic studies and numerous specialized debates about how to deal with the rising costs of providing necessary care for patients in the last period of life have shown that the only reasonable method is to develop ambulatory and stationary palliative care services.

The present study is the first in this country prospective, multi-center statistical and economic analysis of health services provided in five different palliative medicine wards. The analysis was performed at the same time on a group of 175 patients and studied costs incurred by health services providers, who represented public and private units. Previously published analyses were carried out by Tracz et al. [14] in two wards of palliative medicine within the Lodz district. In turn, the pharmacoeconomic analysis published in 2000 by Dziadziuszko et al. [25] presented the results of a survey conducted retrospectively in palliative care units in the region of Pomerania. The aim of that study was to compare mean costs of hospitalization in stationary units and costs of domestic palliative care, as well as in internal medicine wards from the perspective of the payer (Sickness Fund/Patients' Fund) [25].

The results of the present study showed that the mean cost of hospitalization per person per day in the studied PCU, which on average was 81.9 EUR (352 PLN), was significantly higher than the average payment for the care per person per day made by PU NHF in 2012 (52.8 EUR; 227 PLN).
As a consequence, the balance settlement, unprofitable for health services providers, revealed that real costs per person per day incurred by health services providers are not covered in the studied PCUs due to the underestimation of the reimbursement rate used by the NHF. Oral information from heads of these units suggests that due to this economic deficit reaching $40 \%$, PCUs make a financial loss in the balance of profits and losses for the full year. In accordance with current statutory regulations, palliative care services, regardless of the founding body and their organization form, should care about a positive profit and loss balance. This unfavorable situation of palliative care units has lasted for nearly 10 years.

Furthermore, the results of this study indicate a high proportion of medical staff remuneration in direct costs, which amounted to $52 \%$, as well as overhead expenses, which amounted to $30 \%$ of all costs. It should be emphasized that the average hourly rate of remuneration of medical staff employed by the PCUs was 3 EUR (13 PLN) (gross) and was respectively 0.93 EUR (4 PLN) higher and 2.3 EUR (10 PLN) lower than the minimum and the average salary announced by The Polish Central Statistical Office (GUS) for 2012 [26].

Other direct costs accounted for a smaller percentage of the total costs. Expenditures on drugs accounted for $7 \%$, medical materials $5 \%$ and diagnostic tests $1 \%$. Similar results were obtained in a prospective study conducted in 4 palliative care units in France, where medical staff salaries accounted for $62.1 \%$ of total costs, hotel costs (meals, laundry, etc.) $22.7 \%$, costs of depreciation on premises $5.4 \%$, costs of disposal equipment $3.5 \%$, costs of diagnostic tests $1 \%$, and expenditures on medicines $4.7 \%$ [27]. In turn, the results of a study conducted in Australia showed that direct costs associated with the remuneration of nurses, physiotherapists and psychologists were treated as key ones and accounted for over $90 \%$ of total costs [28]. In the current study, overhead expenses calculated using the 'top-down' method accounted for $30 \%$ of total costs, and they were similar to the results of analysis conducted in palliative care units in France, where hotel costs (laundry, meals, etc.) accounted for $22.7 \%$ and the costs of depreciation on premises accounted for $5.4 \%[27]$.

Mean cost per person per day in analyzed PCUs was much lower than in the results of available studies carried out in the EU and America. The analysis of costs per person per day of 140 patients hospitalized in PCUs in France revealed that these costs, depending on where the palliative care was provided (in an 'acute' hospital or in a long-term care hospital) amounted to 482 EUR (1894 PLN) and 388 EUR (1524 PLN), respectively [27]. This difference was associated with the em- 
ployment of more medical staff in a palliative care ward in an 'acute' hospital. The results of the analysis of costs per person per day in 6 hospitals in Belgium providing palliative care in 'regular' hospital departments (cardiology, geriatrics and oncology) showed that the costs amounted to 283 EUR (1064 PLN) and were lower than in specialist palliative care units, where they amounted to 522 EUR (1962 PLN) [1]. This difference resulted from various rates of medical staff employed, mainly nurses. In 2007 in palliative care units there were 1.5 nurses per bed, while in the 'regular' wards the ratio was $0.4-0.5$ of the equivalent of a part-time nurse per bed [1]. Estimated costs per person per day used in palliative care by Marie Curie Cancer Care are 145 GBP (591 PLN) in the case of domestic care and 425 GBP (1734 PLN) in the case of stationary palliative care [29]. The results of the analysis of costs per person per day in the case of patients dying in an 11-bed palliative care unit at the University Hospital of St. Tomasz in Virginia showed that direct costs were 700 USD (2093 PLN) and were significantly lower in comparison to the cost of hospitalization in an Intensive Care Unit and other wards, where costs amounted to respectively 2500 USD (7475 PLN) and 1000 USD (2999 PLN) [7]. As demonstrated by the results of a study conducted in palliative care wards in France, the height of costs of palliative per person per day may be influenced by important clinical factors associated with treated patients, such as the degree of anxiety of the patient and/or caregiver, the terminal phase of the disease, tumor location in the gastrointestinal tract, or the relatively young age of the patient [27]. The authors of this study suggest that these clinical conditions require greater involvement of specialist medical staff, which results in higher direct costs associated inter alia with the employment of medical staff. Therefore, the authors of this study propose introducing the diagnosis-related group (DRG) system components widely used in the 'acute' hospital wards to the heterogeneous population of terminally ill patients. Charging for the entire stay of the patient in the ward may pose another model of funding [27, 30]. In France, the highest reimbursement for hospitalization is obtained for the stay of a patient at a specialist PCU. In 2006 this reimbursement was 9051 EUR (38 919.3 PLN), the reimbursement for hospitalization in a hospital ward with 'separate beds' for terminally ill patients was 8404 EUR (33 027 PLN), and it was 6465 EUR (25 $407 \mathrm{PLN}$ ) for palliative care in a ward without 'separate beds' [27]. In this method of financing, the payer has introduced mechanisms that limit both too short and too long hospitalization (35 days). The results of the present study showed that the average cost of hospitalization in a PCU amounted to 1194.2 EUR (5135 PLN) and the mean hospital stay was 15 days. Taking into account the fact that in Poland the average salary adjusted to purchasing power parity (PPP) is approximately twice as low as the EU average, mean costs per person per day and costs of hospitalization are much lower in Poland than in Western Europe or the United States [31]. However, we should be cautious when comparing direct costs of care in different countries due to the different models of palliative care and the different groups of patients, as well as differences in the standard of health services [1]. The Australian National Sub-acute and Nonacute Patient Classification is the most detailed way of settlement of costs of hospitalization of patients in palliative care. The results of an analysis published by Eagar et al. [12], based on the observation of 3866 patients in palliative care in Australia and New Zealand, showed 11 classes of hospitalization, to which appropriate costs could be ascribed. The results of this study are surprising in that they demonstrated the possibility to anticipate patients' needs and the cost of meeting them without using the current approach, which is based on the ICD-10 diagnosis and ICD-9 procedure codes. According to Eagar et al. [12], costs depended mainly on the stage of the disease (stable, unstable, deteriorating, phase of dying), functional status (according to the Katz Index of Independence in Activities of Daily Living (ADL) scale) and patient's age.

The fundamental weakness of the current method of calculation of actual costs of care is that it is focused on the health service providers. For this reason, a number of other important indirect costs, which are borne by the health care system as a whole, the economy and society, were not taken into account. In the case of patients hospitalized in the PCU, costs incurred by the patients themselves and their families or caregivers were not taken into consideration. The importance of social costs that are difficult to estimate and associated with an incurable disease and patients' and their close relatives' suffering as well as the use of inappropriate forms of medical care should also be emphasized. The World Health Organization (WHO) established the category of 'social costs' which describes the lost social welfare both in monetary terms (reduction of income of the patient, close relatives or caregivers) and in terms of costs that are difficult to express in monetary units, such as pain, suffering, loss of free time and decreased quality of life due to severe disease [32].

Direct costs included remuneration for employees, but the costs of informal care done mostly by volunteers, relatives or other caregivers were not calculated. The assessment of the costs of palliative care from the perspective of the family, or 
caregivers, could probably reveal how high the real costs incurred by society are. Therefore, persons who decide about the health care system should be interested in learning about all possible costs which are associated with incurable disease and how to properly allocate social resources in the health system and social welfare. Palliative care through a comprehensive multidisciplinary team deals not only with symptoms but also with psychosocial needs of the patient, and when the patient is dying it provides help to the patient's family or caregivers. In some units the costs associated with the pharmaceutical department were not counted [19]. Selected PCUs represented a high standard of care, but they were organizationally related to University Hospitals, so they carried out both health services and university pre- and post-graduate education, which could have an impact on both direct costs and overhead expenses. Also, the way of medical statistics preparation and the method of settlement with the NHF in which the day of admission and discharge is treated as one day resulted in the loss of an average of 29.1 EUR (125 PLN) per person per day of hospitalization. It should also be taken into account that many units participating in this study worked under economic pressures associated with considerable economic deficit, which might have contributed to the reduction of many costs, especially those associated with medicines, diagnostic tests and the number of employees and the reimbursement for employees, which was reflected by the low mean salary per hour of work - 3 EUR (13 PLN gross). Although the requirements of the NHF are common for all health service providers in Poland, there are geographical differences in the PU NHF valuation of costs per person per day, and they are equal to 52.3 EUR (225 PLN) in Kujawsko-Pomorskie region and 57 EUR (245 PLN) in the neighboring region of Wielkopolska. It appears that the actual cost of hospitalization per person per day should be considerably higher than that shown in the present calculations. According to estimates of units participating in the present study, but also according to oral information from managers of units which did not participate in the study, the mean cost of treatment per person per day should be approximately 111.6 EUR (480 PLN). Therefore, further detailed studies taking into account certain limitations associated with results obtained in the present study are necessary.

In conclusion, this prospective, simultaneous analysis performed in five PCUs showed that the actual value of mean cost per person per day is much higher than the average payment per person per day offered by PU NHF. The results of the present study should be the basis for the renegotiation of payment which is currently offered to health service providers by the NHF so that it corresponds to the actual cost of care [33]. In the future, apart from the analysis of costs per person per day, cost-effectiveness and cost utility including final effects such as the quality of life and the degree of satisfaction of patients with palliative care should also be analyzed.

\section{Acknowledgments}

I would like to thank many people who worked systematically during the collection and reporting of data concerning direct costs, those who sacrificed their precious time to prepare reliable payroll and accounting forms in the units of palliative care, and also those who have spared no criticism and provided specialist advice. Therefore, special thanks go to Halina Bogusz, Agnieszka Szreder, Ilona Lutostański, Marcin Ziolkowski, Ireneusz Prutkowski, Violetta Matecki and Krzysztof Kuraś.

\section{Conflict of interest}

The authors declare no conflict of interest.

\section{References}

1. Simoens S, Kutten B, Keirse E, et al. Costs of terminal patients who receive palliative care or usual care in different hospital wards. J Palliat Med 2010; 13: 1366-9.

2. Higginson IJ, Gomes B, Calanzani N, et al.; PRISMA Project. Priorities for treatment, care and information if faced with serious illness: a comparative population-based survey in seven European countries. Palliat Med 2014; 28: 101-10.

3. Dumont S, Jacobs P, Fassbender K, Anderson D, Turcotte V, Harel F. Costs associated with resource utilization during the palliative phase of care: a Canadian perspective. Palliat Med 2009; 23: 708-17.

4. Regulation of the Minister of Health on guaranteed benefits in the field of palliative and hospice care of 29.08.2009 with further amendments [Polish].

5. Penrod JD, Deb P, Luhrs C, et al. Cost and utilization outcomes of patients receiving hospital-based palliative care consultation. J Palliat Med 2006; 9: 855-60.

6. Gómez-Batiste X, Tuca A, Corrales E, et al.; Evaluación-SECPAL, Grupo de. Resource consumption and costs of palliative care services in Spain: a multicenter prospective study. J Pain Symptom Manage 2006; 31: 522-32.

7. White KR, Stover KG, Cassel JB, Smith TJ. Non-clinical outcomes of Hospital-based palliative care. J Healthcare Manag 2006; 51: 260-73.

8. Smith TJ, Coyne P, Cassel B, Penberthy L, Hopson A, Hager MA. A high-volume specialist palliative care unit and team may reduce in-hospital end-of-life care costs. J Palliat Med 2003; 6: 699-705.

9. Czerw Al, Kowalska M, Religioni U. Differences in the use of outsourcing in public and private institutions providing medical services. Arch Med Sci 2014; 10: 618-29.

10. Hatziandreu E, Archontakis F, Daly A. National audit Office. The potential cost savings of greater use of homeand hospice-based end of life care in England. National Audit Office 2008. 
11. Gade G, Venohr I, Conner D, et al. Impact of an inpatient palliative care team: a randomized control trial. J Palliat Med 2008; 11: 180-90.

12. Eagar K, Green J, Gordon R. An Australian casemix classification for palliative care: technical development and results. Palliat Med 2004; 18: 217-26.

13. Eagar K, Gordon R, Green J, Simth M. An Australian casemix classification for palliative care: lessons and policy implications of a national study. Palliat Med 2004; 18:227-33.

14. Tracz M, Wieczorek J, Orszulak-Michalak D. The assessment of the costs of care of patients with small cell lung cancer in stationary Hospice-Palliative Care. Farmakoekonomika 2007; 11: 3-11.

15. Regulation of the Minister of Health of 29 July 2011. Official Journal of the Ministry of Health 6 pos. 50 [Polish]

16. Ciałkowska-Rysz A, Dzierżanowski T. Assessment of the situation of palliative care in Poland in 2012. Medycyna Paliatywna 2012; 4: 210-6.

17. Ciałkowska-Rysz A, Kowalczyk M, Gottwald L, Kaźmierczak-tukaszewicz S. The comparison of common cancer types and the coincidence of concomitant chronic diseases between palliative home care patients in Lodz Voivodeship and the general Polish population. Arch Med Sci 2012; 8: 496-503.

18. Regulation of the Minister of Health of 18.04 .2012 on the management of healthcare entity performing medical activities in the field of stationary and twenty-fourhour care over the body of the patient in case of patient death [Polish].

19. Act of 6 September 2001. Pharmaceutical Law, Act on medical activity, 2011 [Polish].

20. Regulation of the Minister of Health of 21.12.2010 on the medical records [Polish].

21. Article $19 f$ of the Law of 5.12 .1996 on the professions of doctor and dentist [Polish].

22. Act of 15.04 .2011 on medical activity [Polish].

23. Rice DP. Estimating the cost of illness. Am J Public Health Nations Health 1967; 57: 424-40.

24. NHF Statement of 07.02.2011 on rules on the reporting of benefits settled in 2011 [Polish].

25. Dziadziuszko R, Konopa K, Jassem J. Health economic issues in palliative care. Psychoonkologia 2000; 6: 3-7

26. http://www.gus.pl/strona/dane-statystyczne-2012

27. Tibi-Lévy Y, Le Vaillant M, de Pouvourville G. Determinants of resource utilization in four palliative care units. Pall Med 2006; 20: 95-106.

28. Eagar K, Green J, Gordon R. An Australian casemix classification for palliative care: technical development and results. Palliat Med 2004; 18: 217-26.

29. Marie Curie Cancer Care. Understanding the cost of end of life care in different settings. NHS Operating Framework 2003.

30. Tibi-Levy Y, D'Herouville D. Developing an operational typology of patients hospitalised in PC units. Palliat Med 2004; 18: 248-58.

31. Jodłowska M. Wages in Poland as compared to the European Union in the period 1990-2013. www. wynagrodzenia.pl. Available at: 17.11.2014 [Polish].

32. World Health Organization 2002.

33. Czerw Al, Kowalska M, Religioni U. Differences in the use of outsourcing in public and private institutions providing medical services. Arch Med Sci 2014; 10: 618-29. 